\title{
The Effectiveness Of Election Silence According To PKPU (Regulation Of The General Election Comission) NO. 23 of 2018 Concerning Election Campaigns On Social Media
}

\author{
Nynda Fatmawati ${ }^{1}$, Anisatul Ulfa ${ }^{2}$ \\ \{ninda.fatmawati@narotama.ac.id ${ }^{1}$, anisatululfa17@gmail.com² \\ Narotama University, Arif Rahman Hakim Street no. 51르, NarotamaUniversity, Arif Rahman Hakim \\ Street no. $51^{2}$
}

\begin{abstract}
This study aims to look at the effectiveness of election silence legality related to PKPU (Regulation of The General Election Commission) no. 23 of 2018 concerning the Election Campaign for sympathizers on social media ahead of the 2019 presidential election. The method of this research is normative legal research which, among others, reviews PKPU no. 23 of 2018 on Election Campaign and Law no. 7 of 2017 on General Elections. The result shows that PKPU regulates sympathizers of supporting candidates to be officially registered, but social media accounts of those sympathizers are not included to campaign team accounts that have to be registered. Such fact raises speculation on the possibility of using those accounts as tool in conducting a covert campaign during Election Silence by campaign team. Thus, the aim of election silence which is to give prospective voters the opportunity to calmly consider before deciding can't be obtained. The limitation of registration quota of the social media accounts of campaign teams is not in line with the large number of sympathizers who use social media as tools to influence community for choosing the supported candidate.
\end{abstract}

Keywords: Presidential Election, Election Silence, Campaign.

\section{Introduction}

General election is a celebration for Indonesian. Democracy is closely related to the rule of law because in democratic literacy, election is one of the nine principles of state law [1], [2].General election is part of the implementation of the principles of democracy [3], [4], which in this case, people have the right to choose representatives who are trusted to convey their aspirations.

The presence of mass media is increasingly helping people in making choices. Each year, the role of mass media as means for promoting candidates is getting stronger. The media is employed by not only individuals (legislative candidates, presidential candidates and vice presidential candidates) but also political party. The usage of it may look new, but the increasing popularity of media has actually developed and has been liberated since the 1999 general 
election, which then it has become stronger in the 2004 elections to the 2009 elections. Susilo Bambang Yudoyono's victory in the 2004 presidential election was the success of his political marketing, as it is known that the democratic party was not the winning party [5], [6].

The 2019 General Election is as dynamic as the elections in previous years. It is more distinct because it is carried out simultaneously to elect representations for DPR (People's Representative Council), DPD (Regional Representative Council), provincial council, and regency/municipal council (DPRD Provinsi and DPRD Kabupaten/Kota)as well as to vote for President and Vice President. It is predicted as the largest national democratic celebration [7][10]. Based on Article 1 no 1 of Law no. 7 of 2017 on General Elections "General Elections (Pemilihan Umum), hereinafter referred to Pemilu is a means of people's sovereignty to vote for DPR (People's Representative Council), DPD (Regional Representative Council), President and Vice presidents, as well as DPRD(regency/municipal council)...".

For the first time in country's history, PKPU regulation is implemented especially for the presidential election. The campaign involved enormous amount of supporters or commonly referred to open campaign was held on September $23^{\text {th }}, 2018$ until April 13 ${ }^{\text {th }}, 2019$. This rule applies to Candidates of DPR, DPD, and DPRD as well as President and Vice President Candidates. In this year's Presidential Election, there are two pair candidates; Jokowi-Amin and Prabowo-Sandiaga.

Election is held by election organizers, namely the General Election Commission (KPU). KPU has duty to make election rules for every phase, this as stated in article 12 letter c of the Election Law "... compiles KPU's Regulation for each phase of the election ...". Then, KPU formulates PKPU (Regulation of The General Election Commission). As in the 2019 election, KPU employs PKPU no. 23 of 2018 on the General Election Campaign. The General Election Commission regulates that before the Election Day, there will be a period when each supporting presidential candidates political party is prohibited from campaigning. This period is referred to Election Silence. April 14 ${ }^{\text {th }}, 2019$ until April 16 ${ }^{\text {th }}, 2019$ is Election Silence. Previously, political parties were given 21 days to advertise and campaign in various media [11]. They campaign on print media, television, and social media. Print media and television have always been utilized. Not a new thing. Unlike the internet which is a new medium for campaigning.

The usage of social media is similar with internet usage in general, unlimited. Social Media reaches various layers of society. Most people in the world access social media. Social 
media is even used as a 'reference' to represent individual, product or activity. Indonesia is a country with a very large number of social media users.

Observing the United States, it is known that the use of the Internet and social media as a tool for political campaigns has long been carried out in United States Presidential election. In 2000, John Mc Cain understood that web technology could be used as a campaign tool, not merely as a marketing tool. So, in his campaign he spearheaded the use of e-mail as a fundraising tool as well as building relationships with voters. From early 2002 to 2004, Karl Rove and the Republican National Committee pioneered the use of microtargeting using their Voter Vault database. Microtargeting helps candidates focus and pay attention to issues that are considered to help them win [12].

Campaigns as well as political participation in the past and today have different goals. In the past, the form of political participation was more conventional by taking action on the streets, demonstrating or boycotting as well as using old media such as radio, television, newspapers and films which should be performed through a long and limited process. Channel between the Source and the Receiver which is accompanied by Feedback is limited. Today campaign uses more advanced technology such as political participation through internet and social media. This type of campaign tends to be more individual, spontaneous (ad-hoc), based on certain issues and less related to social differences [13]

Young people are more reachable because social media has a strong influence on users. As explained by the innovation-diffusion theory, communicators who get messages from mass media are very strong to influence people, so that there is innovation, then diffusion through mass media which strongly influences people [14], [15]. According to Rogers and Shoemaker (1971), diffusion is a process in which a discovery is spread to the community in a social system. The diffusion-innovation theory positions the role of mass media as agents of social change that have a strong influence on society. When something new comes up, people tend to be curious and feel encouraged to share with others. Then, the mass media facilitates the introduction of this new thing [16], [17].

In Indonesia, the recent trend of campaigning on social media has increased since the election and was responded quickly by the government by preparing appropriate regulations. KPU as a national, permanent and independent Election Organizing institution has prepared rules regarding campaigns through social media since 2018, which was implemented in this 2019 election. This rule is stated in Regulation of the General Election Commission no. 23 of 
2018 on Election Campaigns (hereinafter referred to as PKPU on Election Campaigns). One of the things is a regulation requiring candidates to register their respective campaign teams. This is one of the implementations of the functions of KPU, namely coordinating, organizing and controlling all stages of the general election in accordance with Law No. 22 of 2007 on General Election Organizers. The obligation to register the campaign team aims to find out who are included in the campaign team so that there are no violations during the election process, including during election silence.

\section{Research Method}

The research method used is a normative method that employs legal rules of Indonesian and International standards. The rules include KPU Laws and Regulations. The first step is selecting the case to be discussed. Then literature review is carried out to support case analysis. After that, a case analysis is carried out using data that has been collected previously and then will be followed by discussions to draw conclusions. From the discussion, a conclusion can be formulated.

\section{Result and Discussion}

In political realm, people are required to actively participate in political activities, For example choosing state leaders, and influencing government public policy either directly or indirectly. In general, this activity includes actions such as: 'voting'; attending 'campaign'; becoming a member of a party or interest group; making an approach or relationship or 'contacting' government officials, or members of parliament and so on. Referring to the explanation above, people's participation can be by joining party as a member.

The definition of the campaign team is included in article 1 number 23 PKPU on Election Campaigns. The campaign team is the representative of candidate pair. The campaign team is the bridge between the candidate to the prospective voters. The campaign team is also responsible for delivering information along with the vision and mission carried by the candidates so, from the initial process, a list of names for each party's campaign team members must be submitted. This rule is stated in the article 9 of PKPU on Election Campaigns 
"(1) Candidates, Political Parties and / or coalition of Political Parties are required to register the Campaign Team as referred to Article 8 paragraph (2) to:

a. KPU, for the national level Campaign Team;

b. Provincial KPU / Aceh KIP, for the provincial level Campaign Team; and

c. Regency / City KPU / KIP, for regency / city level Campaign Teams and sub-district and / or village level Campaign Teams or others. "

The article requires the candidate to register their campaign team, starting at the national, provincial to district / city levels. Basically, the main function of political parties is to seek and maintain power. This is done in order to realize its programs based on certain ideologies through the mechanism of elections. To realize this, political parties seek broadest support from the community so that this goal can be achieved [18].

Recently, people are actually active in the election process. Each supporter of the presidential and vice presidential candidates provides support through their social media accounts. Thus, they participate in the 'campaign' activity. Realizing this, KPU creates a legal basis for those. In a way, the presidential and vice presidential candidates winning teams are required to register the official social media accounts used for campaigns. Article 35 of PKPU on Election Campaign stipulates Election Participants are allowed to carry out Campaigns through social media. Registration of the account is also regulated in PKPU Article 36 paragraph (1):

"The Campaign team must register the official Social Media account as referred to in Article 35 paragraph (2) to:

a. KPU, for candidates of President, Vice President and DPR (People's Representative Council);

b. Provincial KPU / Aceh KIP, for candidates of DPD (Regional Representative Council), and DPRD (provincial council); and

c. Regency / City KPU / KIP, for candidates of regency/municipal council (DPRD Provinsi and DPRD Kabupaten/Kota) "

Based on the article above, president and vice president candidates must register their official account to KPU. The official account is one that is deliberately made to communicate the idea, vision and mission of the candidate pairs. Social Media accounts can be made at most 10 (ten) for each type of application. 
Reporting from Kumparan (September 29 ${ }^{\text {th }}$, 2018), Jokowi-Amin reports on his social media accounts of Facebook, Twitter, Instagram and Youtube. The following is the official account of the candidate pair used for campaigning. Any information released through registered social media accounts is considered official statements which are made by their respective teams.

As mentioned earlier, Article 35 paragraph (2) PKPU requires not only campaign team but also official accounts to be registered. The difference is in the quantity. The amount of campaign team member is not restricted, which is different from the number of social media accounts. The number of each campaign team depends on the decision of each candidate. Jokowi-Maruf Amin registered 5,279 people as members of their campaign team, and PrabowoSandi registered 94 people as members of their campaign team.

On the other hand, advertisements and news used for campaigns are everywhere on social media. This comes from unregistered sympathizer accounts. On twitter, people who have similar tasks as 'sympathizers' are called buzzers. The buzzer is literally a device that produces noise that attracts attention. The buzzer referred to in Twitter is an account that has a large influence, fanatical followers, their tweets are often retweeted, actively interact with followers and have a large number of followers [19], [20].

Sympathizers carry out 'campaigns' on social media as a form of support for certain candidates. In conclusion, these accounts also participate in the campaign process, but are not registered. These Sympathizers are not registered. They have various backgrounds with a variety of skills. Making an interesting campaign material is certainly not difficult for sympathizers who have expertise in the IT field. So how is the effectiveness of article 35 paragraph (2) PKPU on Election Campaigns for the sympathizers' accounts? Can they also be ruled by PKPU if they do a 'campaign' during election silence?

Preferably, election silence should be understood first. In article 1 no 34 PKPU on Election Campaigns

"Election Silence is a period that cannot be used to carry out Election Campaign activities."

The goal of election silence is to create cooling-off atmosphere before the day of vote, giving the opportunity for voters to consider the candidates based on their knowledge during the campaign period as well as to clear all regional head election props in the public space. In that period, campaign teams of Jokowi-Amin and Prabowo-Sandi were prohibited from conducting campaign activities as referred to article 24 paragraph (4) PKPU on Election Campaigns 
"During Election Silence as referred to paragraph (3), Election Participants are prohibited from carrying out any form of Campaign."

The phrase " any form" can be interpreted that each candidate pair is prohibited from broadcasting advertisements, track records of Political Parties or coalition Political Parties, Candidate Pairs and / or Campaign Teams, or other forms that lead to interests Campaigns that are beneficial or detrimental to Candidate Pairs. This is not only about the form of the campaign, but also the facilities which are employed. Social media is included.

PKPU does not regulate sanctions for candidates who carry out campaigns in election silence period. But, the punishment is regulated in article 492 of Law no. 7 of 2017 on General Elections

"Anyone who intentionally conducts an Election Campaign outside the time scheduled by KPU, Provincial KPU, and KPU l (district / city for each Election Participant as referred to in Article 276 paragraph (2), shall be sentenced to a maximum of 1 (one ) year and a maximum fine of Rp.12,000,000.00 (twelve million rupiah) "

However, what about the sympathizers accounts who are not registered? The sympathizers accounts can be personal or group account which means they are not officially made by each candidate, only made voluntary. Whereas in article 24 paragraph (4) PKPU on Election Campaign prohibits campaigns by campaign teams which are formed by each candidate and bound by these regulations. Apart from that, all accounts that carry out campaigns during election silence, either individual or groups accounts are not bound by the rule. The reason is they are not registered in the campaign team, so there are no attachments between sympathizers and PKPU rules. Automatically, they cannot be subject to sanctions punished by the Election Law. If the purpose of Election silence period is to give voter a chance to decide a choice, do these informal social media accounts respect this?

Some time ago, an online media wrote that the Ministry of Communication and Information would temporarily block social media during election silence. Various responses are emerged within society. One that circulating through social media question the reason behind the decision because utilizing technological is the right of citizens, as explicitly stated in article 19 of the Universal Declaration of Human Rights. Hence, People are free to seek, receive and share all information related to the election without being restricted. In addition, The 1945 Constitution of the Republic of Indonesia also guarantees information disclosure to the public in Article 28F of The 1945 Constitution of the Republic of Indonesia Law no. 39 Year 1999, 
article 14 concerning human rights. Responding to this, the Director General of Information Applications, Semuel Abrijani Pangerapan relayed correction and highlighted that the news was hoax [21]-[23].

It will be difficult to realize the essence and purpose of Election Silence when the rules only apply to registered accounts. A very large number of sympathizers who are not registered like official campaign team accounts ascertain the possibility of 'commotion' during Election Silence on Social Media. Each sympathizer still influences the voters in their own way and does not respect Election Silence period because the rules and sanctions do not apply to them.

\section{Conclusion}

The flaw of the regulation which prohibits the use of social media during Election Silence raises question that such weakness may be used to perform the covert campaigns. Campaign teams may employ sympathizers and / or third party (buzzer) accounts in conducting campaigns in Election Silence period because such accounts are not bound to PKPU on the Election Campaign. Hence, they cannot be punished because the accounts are not under the name of the candidates or supporting parties. Likewise, PKPU can't also be applied to the advertisements of presidential candidates displayed on social media. This action is performed not only in the Election Silence periods but also during general elections.

\section{References}

[1] S. Pemerintahaan-Indonesia.blogspot.co.id, "Pemilu di Indonesia | Sistem Pemilihan Umum,” J. Ilmu Sos. dan Ilmu Polit., 2013.

[2] A. B. Azed, "Sistem Pemilu di Indonesia," J. Huk. Pembang., 2017.

[3] B. Kesgin and J. Kaarbo, "When and how parliaments influence foreign policy: The Case of Turkey's Iraq decision,” Int. Stud. Perspect., 2010.

[4] A. J. Meijer, "Transparent government: Parliamentary and legal accountability in an information age," Inf. Polity, 2018.

[5] A. Wrobel-Leipold, "Content Marketing in der Politik," in Politikwissenschaft als Beruf, 2018.

[6] E. S. Rini, "Peran Pemasaran Politik dalam Mempengaruhi Keputusan Pemilih,” J. Ekon., 2012.

[7] ICW, "Outlook Korupsi Politik Indonesia 2018," Indonesia Corruption Watch. 2018.

[8] T. TRIONO, “MENAKAR EFEKTIVITAS PEMILU SERENTAK 2019,” J. Wacana Polit., 2017.

[9] "Peluang dan tantangan pemilu serentak 2019 dalam perspektif politik," J. Ilm. Ilmu Pemerintah., 2018.

[10] R. Casmi Arrsa, "Pemilu Serentak dan Masa Depan Konsolidasi Demokrasi," J. Konstitusi, 
2014

[11] A. C. Prasatya, "The Role Of Social Media in Indonesia's 2014 Presidential Election Campaign,” J. Ilm. Univ. Bakrie, 2015.

[12] Morissan, "Morissan: Media Sosial dan Partisipasi Sosial," J. Visi Komun. , 2014.

[13] Morrisan, "Tingkat Partisipasi Politik dan Sosial Generasi Muda,” Visi Komun., 2016.

[14] B. Schivinski and D. Dabrowski, "The effect of social media communication on consumer perceptions of brands," J. Mark. Commun., 2016.

[15] M. Laroche, M. R. Habibi, and M. O. Richard, "To be or not to be in social media: How brand loyalty is affected by social media?," Int. J. Inf. Manage., 2013.

[16] L. Pettersen, "From Mass Production to Mass Collaboration: Institutionalized Hindrances to Social Platforms in the Workplace," Nord. J. Sci. Technol. Stud., 2017.

[17] T. J. Blank, "Introduction: Pattern in the Virtual Folk Culture of Computer-Mediated Communication," in Folk Culture in the Digital Age: The Emergent Dynamics of Human Interaction, 2017.

[18] A. D. T. Putra, "INOVASI MODEL SOSIALISASI PERAN SERTA MASYARAKAT DALAM PEMILU," J. Wacana Polit., 2017.

[19] S. C. McGregor, R. R. Mourão, and L. Molyneux, "Twitter as a tool for and object of political and electoral activity: Considering electoral context and variance among actors," J. Inf. Technol. Polit., 2017.

[20] M. Hentschel and O. Alonso, "Follow the money: A study of cashtags on Twitter," First Monday, 2014.

[21] S. R. Veil, J. Reno, R. Freihaut, and J. Oldham, "Online activists vs. Kraft foods: A case of social media hijacking," Public Relat. Rev., 2014.

[22] J. Sloan, “LET'S BE HONEST: SUPER IS BROKE AND WE NEED TO FIX IT," The Australian, 2018.

[23] M. Tambuscio, G. Ruffo, A. Flammini, and F. Menczer, "Fact-checking effect on viral hoaxes: A model of misinformation spread in social networks," in WWW 2015 Companion Proceedings of the 24th International Conference on World Wide Web, 2015. 